\title{
COMPOSITION OF ZOOPLANKTON ASSEMBLAGES ALONG THE ZAGYVA RIVER
}

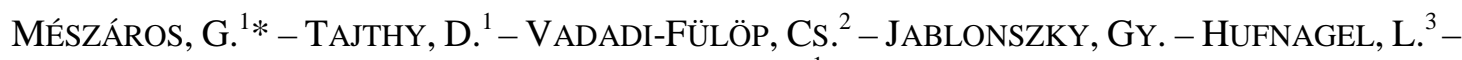 \\ ZSUGA, K. ${ }^{1}$ \\ ${ }^{1}$ Szent István University, Faculty of Agricultural and Environmental Sciences, \\ 2100 Gödöllö, Páter Károly u. 1. \\ ${ }^{2}$ Hungarian Scientific Research Fund Office, \\ 1093 Budapest, Czuczor u. 10. \\ 3 "Adaptation to climate change" Research Group of Hungarian Academy of Sience, \\ 1118 Budapest, Villányi út 39-43. \\ * Corresponding author \\ e-mail: meszarosgergo@freemail.hu \\ (Received $2^{\text {nd }}$ May 2012; accepted $4^{\text {th }}$ October 2012)
}

\begin{abstract}
The species composition, longitudinal distribution and seasonal dynamics of zooplankton were studied in the Zagyva River, Hungary. A total of 108 taxa was recorded from which 61 were new for the river. Rotatoria was the most abundant group, microcrustaceans were less important, only nauplii and copepodites were represented in similar individual numbers. Frequent species included Anuraeopsis fissa, Pompholyx spp., Keratella cochlearis, Brachionus angularis, Bdelloida sp., Bosmina longirostris. Dominance of cosmopolitan species was observed both in the river and its reservoir, and species characteristic of eutrophic waters were of major importance in the latter. There was a downstream decrease in zooplankton densities, which was explained by modified conditions. The relatively large number of individuals in autumn months, and the characteristic large number of individuals in the upper section contrasted general findings of potamoplankton dynamics. On the basis of the species abundance matrix, three river sections can be distinguished (upper, middle, lower section). Due to waste water discharges - received from the Tarján Stream - we found extremely high number of individuals and the lowest diversity at the sampling site Nagybátony (148 rkm).
\end{abstract}

Keywords: Rotatoria, Copepoda, Cladocera, reservoir, spatial distribution.

\section{Introduction}

Despite rapidly growing insights into zooplankton spatio-temporal dynamics, investigations on riverine zooplankton have not yet been given much effort in comparison with lentic systems, mainly due to historical constraints and the flowing character. This is particularly true for low order streams and rivers. With this end in view, however, the distribution of zooplankton along rivers has received relatively considerable attention for a long time. The downstream increase in zooplankton density is well-documented in some rivers (Saunders and Lewis, 1989; Gulyás, 1995a, b; Kim and Joo, 2000; Maria-Heleni et al., 2000; Zimmermann-Timm et al., 2007), however, some authors have found just the opposite (Basu and Pick, 1996; Burger et al., 2002). Generally microcrustaceans play a secondary role in rivers as compared to rotifers, which is explained by the shorter generation time of Rotatoria (Akopian et al., 2002; Lair, 2006) or rotifers are supposed to benefit indirectly from river turbidity because their crustacean competitors and predators are relatively more susceptible to suspended sediments (Thorp and Mantovani, 2005). Microcrustacean communities are often 
dominated by small-bodied cladocerans (e.g. bosmininds) and juvenile forms (copepodite, nauplii) of copepods (Pourriot et al., 1997; Kobayashi et al., 1998; Reckendorfer et al., 1999; Kim and Joo, 2000).

The Zagyva has been poorly investigated regarding plankton communities. Zooplankton studies (Megyeri, 1955, 1971; Gulyás et al., 1995) have not covered the whole river stretch, nor have they analysed spatio-temporal dynamics, moreover those investigations have not focused on the Zagyva alone.

To fill this gap, we aimed to determine the species composition, longitudinal distribution and seasonal dynamics of zooplankton in the Zagyva River within a twoyear study. The Environmental Authority does not measure chemical and hydrological features of the river regularly, therefore the authors cannot address the question how the flow regime governs plankton dynamics in the Zagyva. It follows that we had to confine our discussion to much more descriptive levels.

\section{Materials and methods}

\section{Study site}

The Zagyva is the most remarkable tributary of the River Tisza on its middle section. Its catchment area by the estuary covers $5,677 \mathrm{~km}^{2}$ and it flows into the River Tisza at rkm 334. The fall of water ranges from $16.7 \mathrm{~m} \mathrm{~km}^{-1}$ at the upper, mountainous section, to $1.7-0.64 \mathrm{~m} \mathrm{~km}^{-1}$ at the middle section and $0.12 \mathrm{~m} \mathrm{~km}^{-1}$ at the lower section. The water discharge is primarily determined by rainfall, reservoirs and mines play secondary roles. The $700 \mathrm{~m}$ long Maconka reservoir lies along the upper section of Zagyva and has an average depth of 2-4 m. It is characterized with a prominently rich and diverse fish stock, the shoreline vegetation is comprised of reed, sedge and seaweed.

When selecting the sampling sites we considered (1) preference towards sites downstream of the inflows of the most important tributaries; (2) representative sampling procedure, thus samples were taken from the streamline and (3) conformity to the sampling program of the Environmental Authority. Sampling sites are marked on Fig. 1: Nemti (Ni); Nagybátony (Nb); Petőfibánya (Pb); Gesztenyefasor (Gf); Jászfényszaru (Jf); Szentlőrinckáta (Szl); Jászberény (Jb); Jásztelek (Jt); Újszász (Új). In addition, we collected samples in the Maconka reservoir as well. 


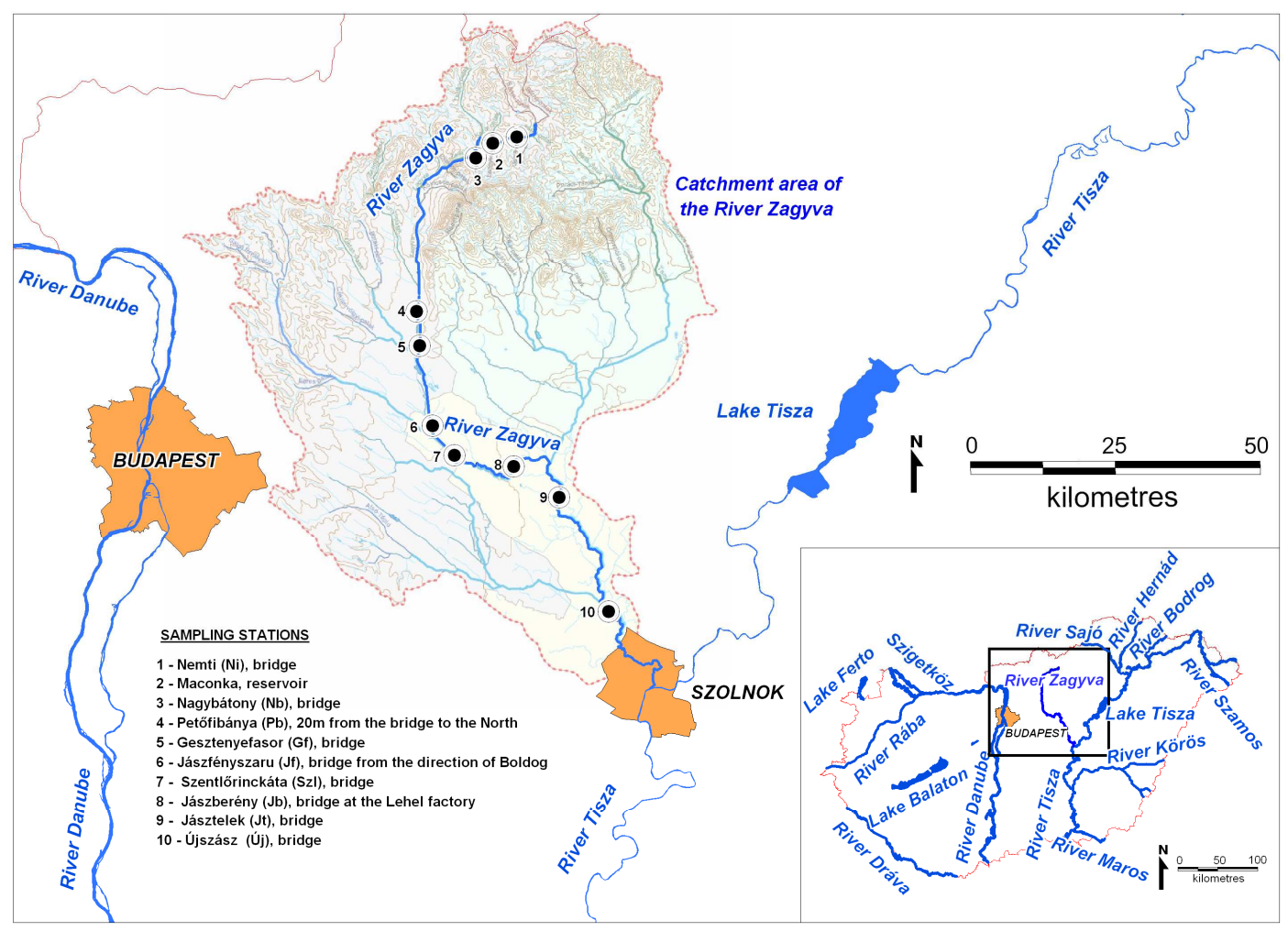

Figure 1. The study area with the sampling sites

\section{Sampling and data processing}

Samples were collected at nine sampling sites along the river and in the Maconka reservoir at biweekly to monthly intervals between March and October 2006, and between June and October 2007, respectively. Samples were taken from the streamline, mostly from bridges. For the purpose of study 50 litres of water (in case of the Maconka reservoir 10 litres) was filtered through a plankton net of $50 \mu \mathrm{m}$ mesh size. The collected material was preserved in situ in $4 \%$ formaldehyde solution. Rotifers and microcrustaceans were counted in $5 \mathrm{ml}$ subsamples in special counting chambers $(70 \times$ $52 \times 5 \mathrm{~mm}$ ) after homogenization. For the taxonomic determination of the animals identification keys by Bancsi $(1986,1988)$ and Gulyás and Forró $(1999,2001)$ were used.

In order to explore the spatial patterns of zooplankton assemblages, cluster analysis and non-metric multidimensional scaling (NMDS) using the Euclidean distance were performed (with standardized data). All data analyses were performed using the PAST software (Hammer et al., 2001).

\section{Results}

During the study period in the whole section of the Zagyva River - including the Maconka reservoir as well - 108 taxa were identified from which 61 were new for the river (Table 1). Brachionus spp., Cephalodella spp., and Lecane spp. were of particular importance. Taxa of Bdelloida, Colurella and Keratella groups almost always occured. 
Crustacean plankton was dominated by nauplii and copepodites, while the cladoceran Bosmina longirostris was the only abundant microcrustacean.

Table 1. The list of taxa identified during the investigation. The ones marked with " $n$ " are new species for the river. Species found in the Maconka reservoir are marked with "Mac" and those found in the inflow of the reservoir are designated with "Inlet"

\begin{tabular}{|c|c|c|}
\hline Rotatoria & F. terminalis ${ }^{n}$ & P. sulcata \\
\hline Anuraeopsis fissa ${ }^{n}$ & Itura aurita ${ }^{n}$ & Proales sp. ${ }^{n}$ \\
\hline Asplanchna priodonta & Keratella cochlearis & Synchaeta oblonga \\
\hline Bdelloida sp. ${ }^{n}$ & K. quadrata & S. pectinata \\
\hline Brachionus angularis & K. testudo ${ }^{n}$ & Synchaeta sp. \\
\hline B. bennini ${ }^{M a c}$ & K. valga & Testudinella mucronata ${ }^{\text {nInlet }}$ \\
\hline B. budapestinensis ${ }^{n}$ & Lecane arcuata ${ }^{n}$ & T. patina \\
\hline B. calyciflorus & L. bulla & T. truncata $^{n}$ \\
\hline B. diversicornis ${ }^{n}$ & L. clara $^{n}$ & Trichocerca agnata $^{n}$ \\
\hline B. falcatus ${ }^{n}$ & L.closterocerca & T. rattus ${ }^{M a c}$ \\
\hline B. leydigi & L. cornuta $^{n M a c}$ & T. taurocephala ${ }^{n}$ \\
\hline B. nilsoni $i^{n M a c}$ & L. elsa $a^{n}$ & T. tenuior ${ }^{n}$ \\
\hline B. quadridentatus & L. flexilis $^{n}$ & \\
\hline B. urceolaris & L. hamata ${ }^{n}$ & Trichotria pocillum \\
\hline $\begin{array}{c}\text { Cephalodella catellina } \\
\text { C. gibba }\end{array}$ & $\begin{array}{l}\text { L. } \text { inermis }^{n} \\
\text { L. luna }{ }^{n}\end{array}$ & $\begin{array}{l}\text { T. tetractis }{ }^{\text {nInlet }} \\
\text { T. } \text { truncata }^{n} \\
\text { Trichotria sp. }\end{array}$ \\
\hline C. megalocephala ${ }^{n}$ & L. lunaris & Cladocera \\
\hline C. misgurnus & L. quadridentata & Alona rectangula \\
\hline C. obvia ${ }^{n}$ & L. scutata ${ }^{n}$ & $\begin{array}{c}\text { Alonella sp. }{ }^{\text {nInlet }} \\
\text { Bosmina longirostris }\end{array}$ \\
\hline C. stenroosi $i^{n}$ & L. subtilis $^{n}$ & Ceriodaphnia laticaudata $^{n}$ \\
\hline C. sterea $a^{M a c}$ & $\begin{array}{l}\text { L. tenuiseta }{ }^{n} \\
\text { Lecane sp. }\end{array}$ & C. recticulata \\
\hline $\begin{array}{c}\text { C. ventripes } \\
\text { Cephalodella sp. } \\
\text { Colurella adriatica }\end{array}$ & $\begin{array}{l}\text { Lepadella ovalis } \\
\text { L. patella }\end{array}$ & $\begin{array}{c}\text { Chydorus sphaericus } \\
\text { Daphnia cucullata }^{n}\end{array}$ \\
\hline C. colurus & Mytilina mucronata $^{n}$ & Daphnia longispina ${ }^{n M a c}$ \\
\hline C. obtusa $a^{n M a c}$ & Notholca acuminata & Disparalona rostrata $^{n}$ \\
\hline Conochilus dossuarius $^{n}$ & N. squamula & Leptodora kindtii ${ }^{M a c}$ \\
\hline Dicranophorus forcipatus ${ }^{M a c}$ & Notommata diasema ${ }^{n}$ & Leydigia leydigi $i^{n}$ \\
\hline D. grandis $^{n M a c}$ & N. dentata ${ }^{n}$ & Macrothrix laticornis \\
\hline D. uncinatus ${ }^{n}$ & N. pachyura $^{n}$ & Moina micrura $^{n}$ \\
\hline
\end{tabular}




\begin{tabular}{|c|c|c|}
\hline Dipleuchlanis propatula $^{n}$ & Paradicranophorus hudsoni ${ }^{n}$ & Pleuroxus aduncus ${ }^{n}$ \\
\hline Encentrum incisum ${ }^{n}$ & Pleurotrocha petromyzon ${ }^{n}$ & Scapholeberis mucronata ${ }^{\text {nMac }}$ \\
\hline E. saudersiae & Polyarthra dolichoptera & Simocephalus vetulus $^{n}$ \\
\hline Euchlanis dilatata & & Copepoda \\
\hline Filinia cornuta $^{n}$ & P. euryptera ${ }^{n}$ & Acanthocyclops robustus ${ }^{n M a c}$ \\
\hline F. longiseta & P. major $^{n}$ & Macrocyclops fuscus ${ }^{n M a c}$ \\
\hline F. opoliensis ${ }^{n}$ & $\begin{array}{c}\text { Polyarthra sp. } \\
\text { Pompholyx complanata }^{n}\end{array}$ & Thermocyclops crassus ${ }^{\text {nMac }}$ \\
\hline
\end{tabular}

In the first year, by taking samples in spring between 15 March and 14 May, 38 Rotatoria, 9 Cladocera and 2 Copepoda species were found. According to the samples taken along the whole river section, a significant difference in the quantitative distribution of the zooplankton assemblage was observed. Our results suggested, that in the samples taken in spring the cladoceran stock was considerable only in the area of Jásztelek and Újszász. Species number and the densities of cladocerans increased during the fall after flood. At the examined sampling sites we found several species of Rotatoria (Notholca acuminata, N. squamula, Keratella quadrata and Synchaeta oblonga), that were the characteristics of colder, spring periods and either disappeared completely from the samples taken in summer or their individual number decreased considerably.

Between 28 May and 27 October 2006, 38 Rotatoria, 6 Cladocera and 1 Copepoda species were identified. Owing to the different ecological conditions in summer - in accordance with the seasonal changes - in the changed composition of zooplankton species exclusively characteristic of the summer survey were found e.g. Anuraeopsis fissa, Encentum saundersiae, Lecane bulla, Pompholyx complanata, P. sulcata, Trichocerca agnata. While examining the samples taken in this period, we observed that number of species of cladocerans decreased in downstream direction. Moina micrura and Daphnia cucullata were characteristic for the upper section, while Ceriodaphnia laticaudata, Ceriodaphnia reticulata and Chydorus sphaericus appeared in the lower section. Nauplii and copepodites of Copepoda were found at each sampling sites in each season. Among adult individuals only Acanthocyclops robustus at Petöfibánya and Thermocyclops crassus at Nemti were found.

By studying the samples taken between 9 June and 28 October 2007, we identified 61 Rotatoria and 9 Cladocera species. In comparison with the previous year some new species appeared in 2007 such as Brachionus falcatus, Cephalodella strenroosi, Lecane quadridentata, Notommata pachyura, Pleurotrocha petromyzon, Trichocerca taurocephala, T. tenuior and Macrothrix laticornis. There was no considerable difference in the common species between the summer and autumn samples but we found three more individuals of cladoceran species compared with the previous year. The number of the existing cladoceran species seemed to be doubled in the studied months. The dominance of Rotatoria was typical except the outflow and the inflow of the reservoir. So, in accordance with the observed quantitative changes we found a more remarkable Copepoda and Cladocera fauna only at the outflow and inflow of the reservoir. Only at these sites - influenced by the reservoir - egg-carrying female individuals in considerable number were found. As regards the registered number of all 
species, the upper section of the river was more various than the lower one, but even so it did not come to the observed number of species in 2006.

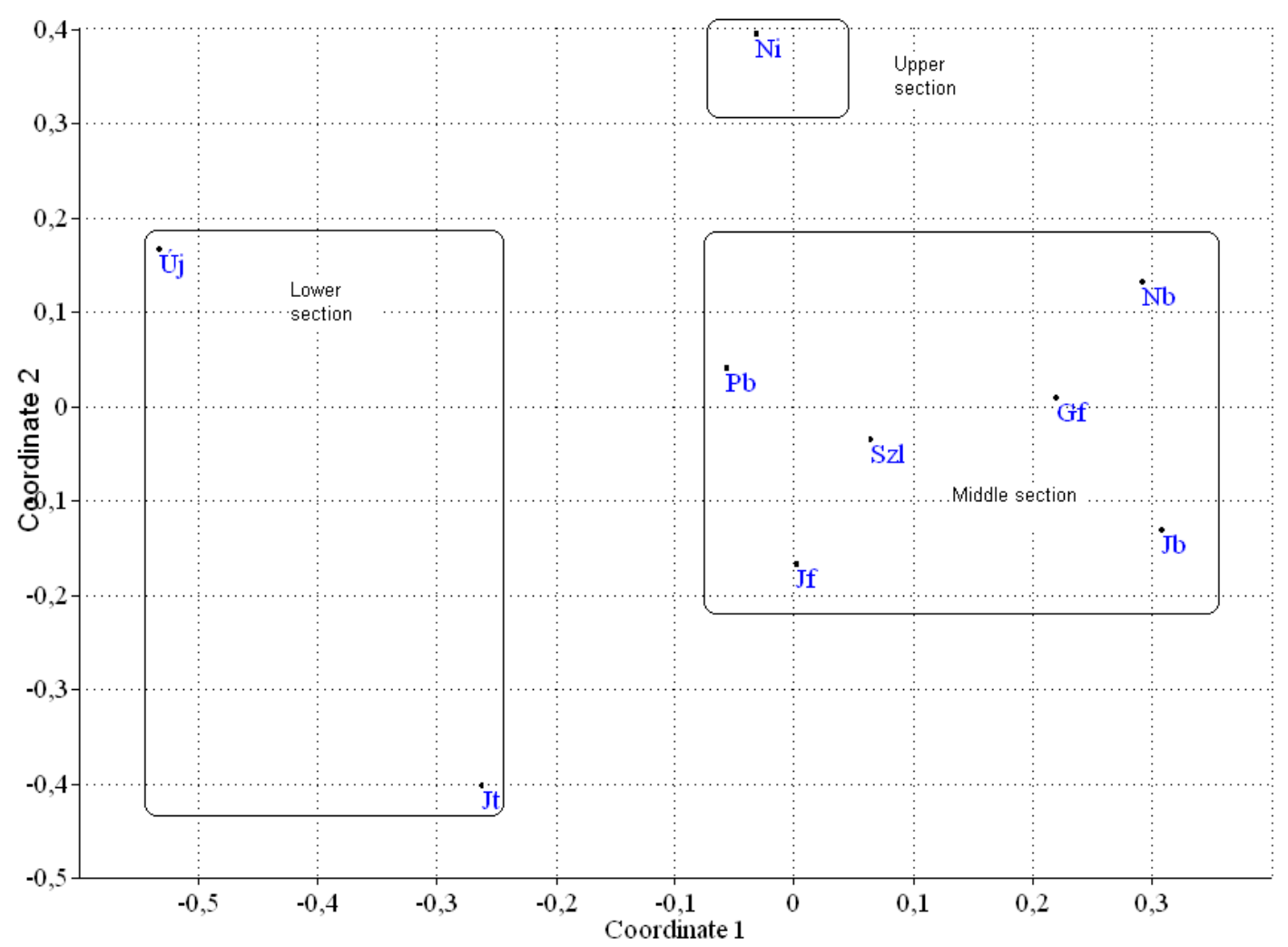

Figure 2. The NMDS plot of the sampling sites. For the abbreviations see Materials and Methods

The NMDS ordination pointed out that the sampling stations form three groups, which can be the equivalents of the upper, middle and lower sections roughly (Fig. 2). The results of the cluster analysis supported these findings (figures not given in the text). In the upper section the Maconka reservoir determines the water quality. The reservoir breaks the "river continuum" with its lentic conditions. So the second section - between the reservoir and Jászberény - is mainly influenced by the reservoir. Jászberény is one of the most important towns in the area with significant industry. At this section the Zagyva is affected by both the waste water loading from the town and by the Tarna that flows into the Zagyva at Jászberény. Therefore we suggest that the third section (between Jászberény and the mouth of the Zagyva) is mostly affected by the above mentioned features.

Beside the NMDS analysis the different sampling sites can be also grouped depending on what kind of species had been taken from the given sampling site. Although the representatives of the most various plankton assemblages can be found on the whole river section there are clear differences in the consistences of the samples collected from the different sections (lower, middle, upper) of the river. Taking samples in 2006 Cephalodella megalocephala, (Ni) Cephalodella obvia, Lepadella ovalis (Pb), Cephalodella misgurnus $(\mathrm{Ni}, \mathrm{Pb})$ and Lecane inermis $(\mathrm{Nb})$ were observed on the upper section of the river. Interestingly both Filinia cornuta and Itura aurita could be found 
only in Jászfényszaru (Jf). While $F$. opoliensis was collected from Jf and $\mathrm{Pb}$ in 2006 , next year this species could be also identified in other sampling sites at the lower section of the river, such as Jt and Új. However Encentrum incisum could be found only in the sample of Jásztelek. Species Brachionus bennini, Dicranophorus forcipatus, Dicranophorus grandis, Trichocerca rattus, Simocephalus vetulus, Macrocyclops fuscus were collected only from the Maconka reservoir. These results might give us a hint about the special fauna of the reservoir.

The following two figures (Fig. 3, 4) show the diversity conditions of two sampling years.

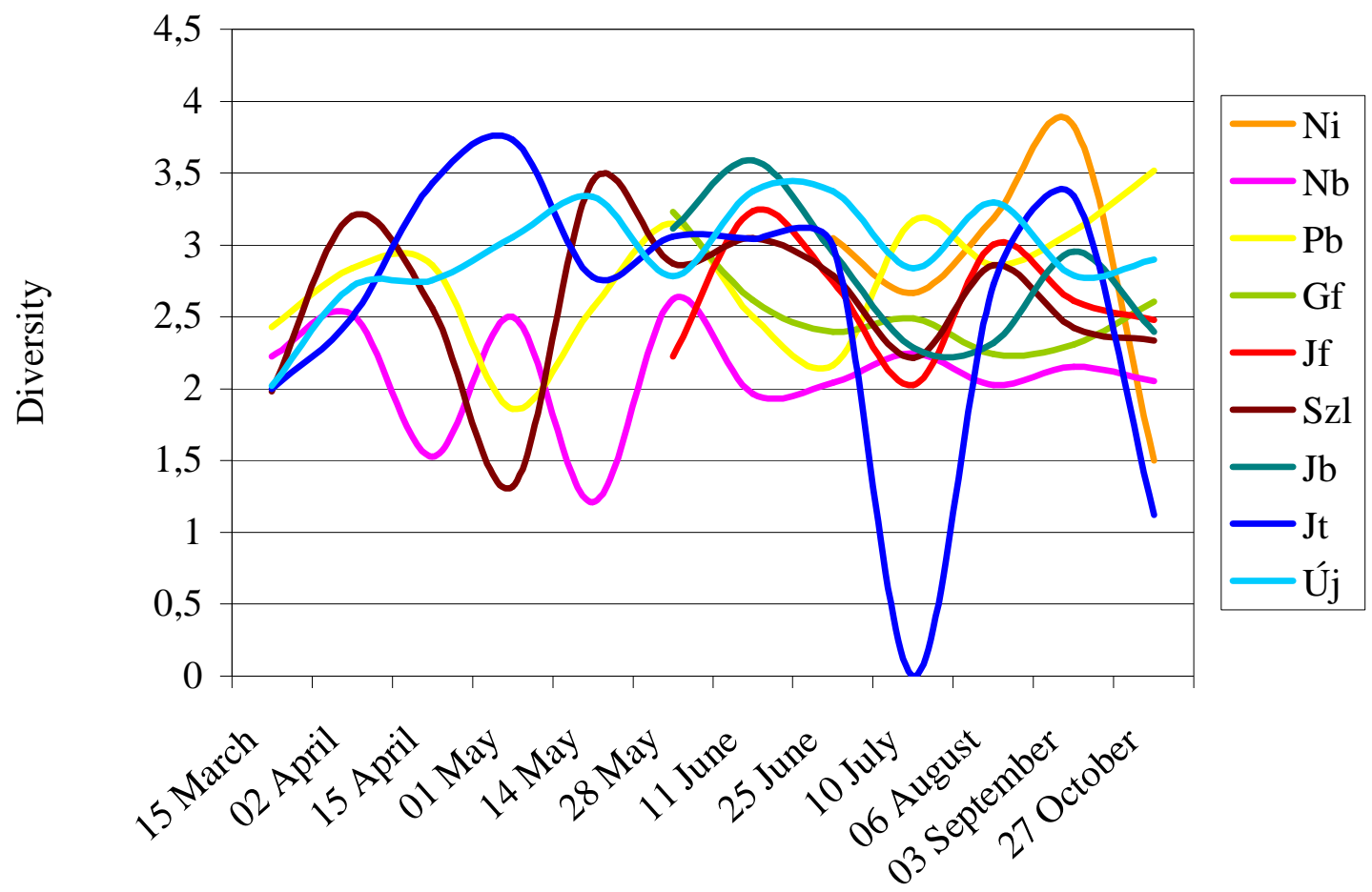

Sampling dates

Figure 3. Diversity conditions (2006)

In 2006, the average diversity reached 2,62. Fig. 3 shows that the diversity varied significantly from March to June. In April the diversity increased at Nagybátony $(\mathrm{Nb})$ but at the same time it decreased at the very next sampling site, Petöfibánya $(\mathrm{Pb})$. This fact can be explained by local conditions. The result of the samples taken on 10 of July can be regarded to be the most interesting point of Fig. 3. This point shows that diversities decreased at all sampling sites with the exception of Nagybátony, Gesztenyefasor and Petöfibánya. Interestingly the most significant decrease in both diversity and the number of individuals was recorded by the sample taken at Jásztelek. This fact may have been caused by the waste water of Jászberény - it is 1,656,077 $\mathrm{m}^{3}$ year $^{-1}$ according to the data kindly provided by the Environmental Authority - flowing into the Zagyva above Jásztelek resulting in a drastical decrease of the species number. This observation can be also explained by the poor quality of the water carried by Tarna 
Stream. Although this above mentioned decline in diversity is the most remarkable it is worth mentioning that similar declines can also be observed at some other sampling sites.

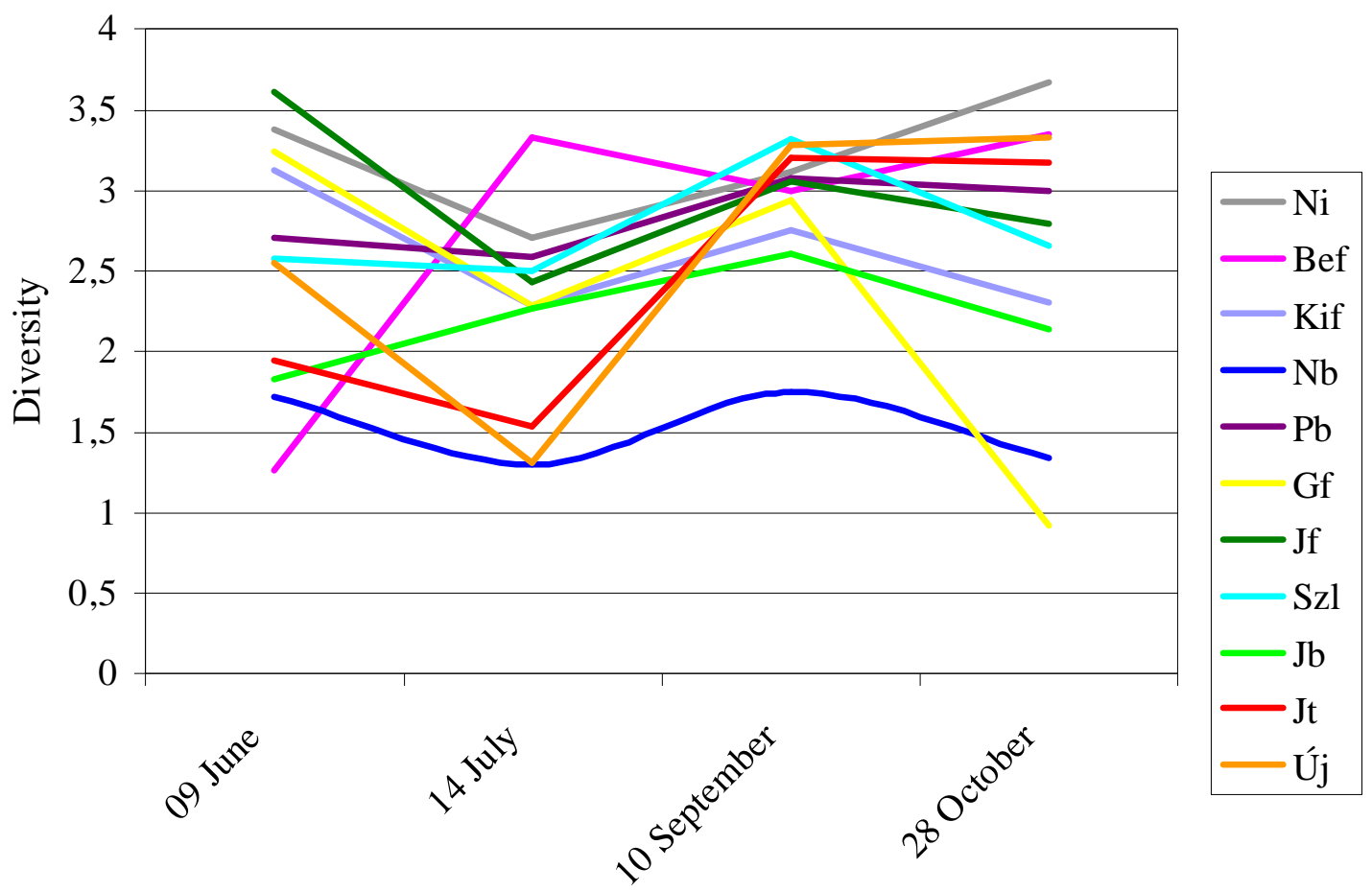

Sampling dates

Figure 4. Diversity conditions (2007)

In the year of 2007, the diversity proved to be more balanced as the average diversity was 2,53 compared with the 2,62 average of the previous year observed in the same period (Fig. 4). The lowest diversity was measured in July but it increased gradually till September. Although the diversity of sampling site marked with Gf seems relatively high and constant till September, it shows a huge drop at the end of October.

In the year of 2006, densities recorded prior to May were extremely low (Fig. 5). We observed remarkably high densities in May at Nagybátony $(\mathrm{Nb})$, but at the other sampling sites densities also increased significantly compared with the previous rate. However, we observed a decrease from May till August. From this time densities rose again considerably and at Nagybátony $(\mathrm{Nb})$ and Gesztenyefasor (Gf) extremely high values were recorded in August. 


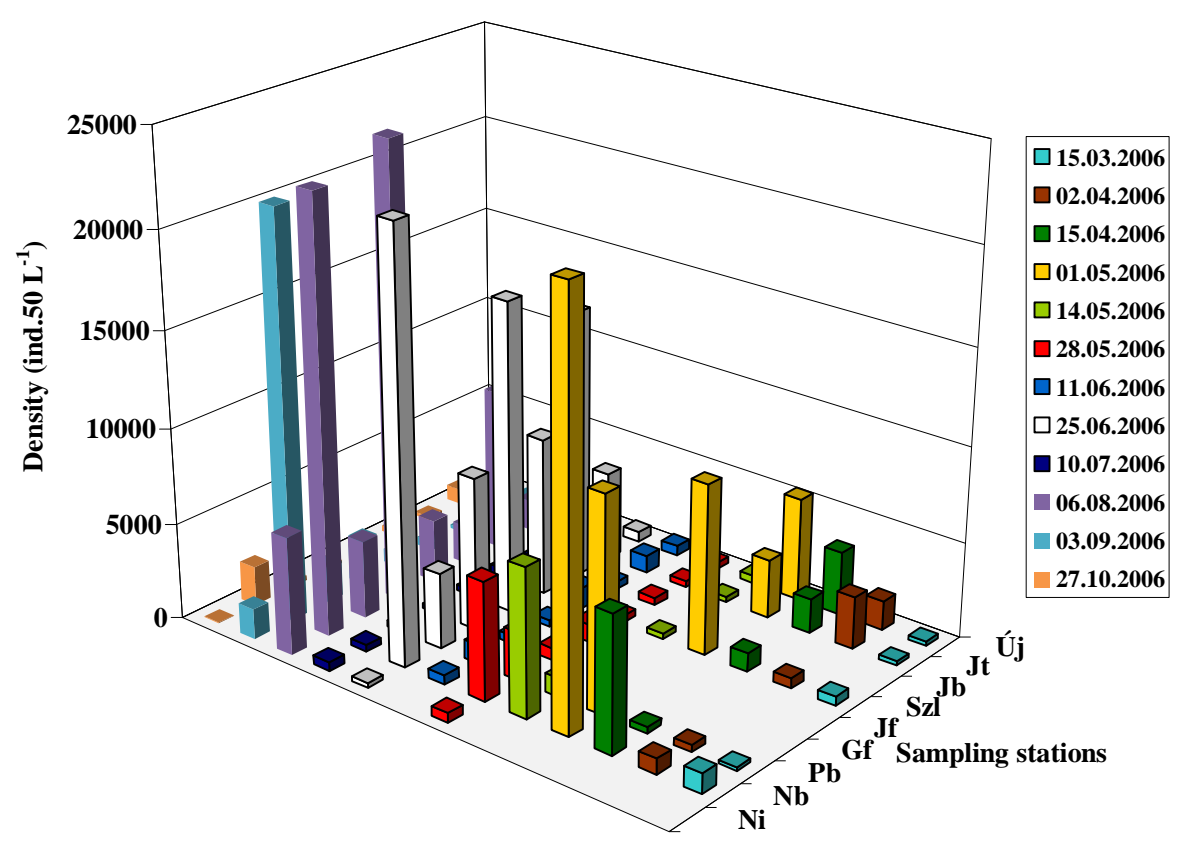

Figure 5. Spatio-temporal dynamics of zooplankton assemblages in the Zagyva River (2006)

In the year of 2007, densities were much more balanced contrasted with the year of 2006 (Fig. 6). In the year of 2007, the sampling date was less determining than the sampling site when densities are concerned, i.e. the spatial dimension explained much of the variability in densities compared to that of the temporal dimension.

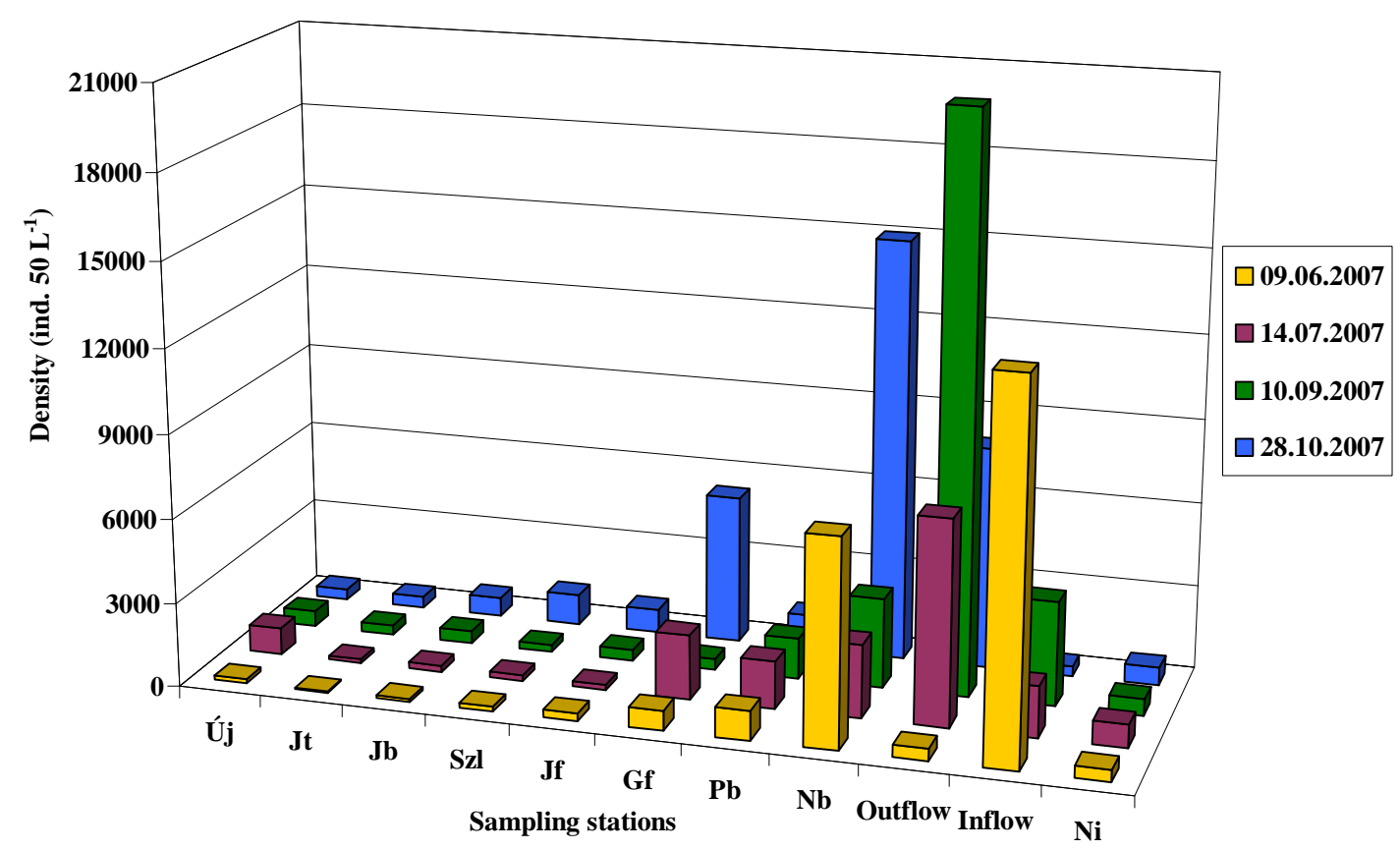

Figure 6. Spatio-temporal dynamics of zooplankton assemblages in the Zagyva River (2007)The terms "Inflow" and "Outflow" refer to the Maconka reservoir 
In Fig. 6 we can observe that densities in 2007 were higher at the upper river sections while appeared to be rather low at the lower river sections.

\section{Discussion}

Generally, findings of potamoplankton studies suggest a downstream increase in densities (Saunders and Lewis, 1989; Gulyás, 1995a,b; Kim and Joo, 2000; MariaHeleni et al., 2000; Zimmermann-Timm et al., 2007) and in summer months a larger number of individuals is typical. But the Zagyva indicated distinct features in several aspects because in the majority of samples, we found that the number of species showed a decreasing tendency from the second sampling site. The above mentioned feature applies to the density as well (Fig. 5, Fig. 6). At Nagybátony, the number of individuals has always been very high except 11 June and 10 July (data not shown). One would argue that the Maconka reservoir, which is situated upstream of Nagybátony, may account for the high number of individuals found at Nagybátony. The abundant nutrient content of waste water carried by Tarján Stream can be a more likely explanation. It carries $11,292,000 \mathrm{~m}^{3}$ of waste water to the Zagyva every year. The river receives $4,200,000 \mathrm{~m}^{3}$ waste water of municipal and 7,100,000 $\mathrm{m}^{3}$ waste water of industrial origin. The total waste water loading exceeds the average water supply of the water body by more than $50 \%$ (data provided by the Environmental Authority). We suggest that the high number of individuals and the dominant species - that are typical of eutrophic waters - such as Keratella, Polyarthra, Filinia are the consequences of waste water loading, because loading the waste water from Györ into the Danube resulted in similar findings (Gulyás, 1995a).

While at Nagybátony the number of individuals was relatively high it was quite low at Újszász and Jásztelek except flood periods. These facts refer to a modified state. In the two-thirds of cases the samples taken at Jászberény showed a larger number of individuals than those taken at Jásztelek or Újszász. Either the waste water from Jászberény loading into the Zagyva just downstream of Jásztelek - it is $1,656,077 \mathrm{~m}^{3}$ year $^{-1}$ according to the data given by the Environmental Authority - or the water of poor quality flowing from the Tarna into the Zagyva River may have caused the decreased number of individuals at Jásztelek and Újszász. These ideas can be a good explanation as Gulyás et al. (1995) also reported a relatively poor fauna of the Zagyva which was attributed to the effects of industrial and communal waste waters. Megyeri (1971) recorded 25 species of Rotatoria, 11 of Cladocera and 2 of Copepoda in the 50s - 60s.

The year of 2007 brought a change because samples were collected at the inflow and outflow of the reservoir regularly. The results we got at the outflow helped us to decide whether the low number of species, and the low value of diversity originate from the previously presented reasons or the difference is due to the effect of the Maconka reservoir. In quantitative respects, in the upper section of the river the number of the individuals was much higher than in the lower section. Generally we suggest the same fact as for the year of 2006, but there was no significant difference in those figures. So based on the quantitative changes of zooplankton the modified state that we experienced in 2006 also existed in 2007. It is important to emphasize that downstream of Nagybátony the mean of the total number of all individuals decreased dramatically. First it fell back up to the one fifth, and one third then from Jászfényszaru up to less than the one-fourteenth. In 2007, we recorded 70 species (61 Rotatoria and 9 Cladocera). It is much less than those recorded in 2006 but it can be explained by the 
less frequent sampling. The dominant species of the river (Bdelloidea, Brachionus quadridentatus, Brachionus urceolaris, Euchlanis dilatata, Keratella cochlearis, Keratella quadrata, Pompholyx sulcata) were typically cosmopolitans. The cosmopolitan Bosmina longirostris of Cladocera occurred at all sampling sites.

Species number and densities of microcrustaceans varied in a similar way along the river. In spite of the significant water supply the number of individuals taken in the lower section was less than those recorded in the upper or middle sections. In this respect we found relatively high number of individuals in the reservoir and at the sampling sites of Petőfibánya $(\mathrm{Pb})$, and Nagybátony $(\mathrm{Nb})$, all situated in the upper section of the river. It can be attributed to the lentic character of the reservoir and the altered environmental conditions downstream, respectively.

Acknowledgements. The authors would like to thank the Environmental Authority for providing the data of waste water inflows.

\section{REFERENCES}

[1] Akopian, M., Garnier, J., Pourriot, R. (2002): Zooplankton in an aquatic continuum: from the Marne River and its reservoir to the Seine Estuary. - C. R. Biologies 325: 807-818.

[2] Bancsi, I. (1986): A guide for the identification of Rotatoria I. - VHB-15. VíZDOK., Budapest (In Hungarian)

[3] Bancsi, I. (1988): A guide for the identification of Rotatoria II. - VHB-17. VÍZDOK., Budapest (In Hungarian)

[4] Basu, B.K., Pick, F.R. (1996): Factors regulating phytoplankton and zooplankton biomass in temperate rivers. - Limnology and Oceanography 41: 1572-1577.

[5] Burger, D.F., Hogg, I.D., Green, J.D. (2002): Distribution and abundance of zooplankton in the Waikato River, New Zealand. - Hydrobiologia 479: 31-38.

[6] Gulyás, P. (1995a): Rotatoria and Crustacea plankton of the River Danube between Bratislava and Budapest. - Miscellanea Zoologica Hungarica 10: 7-19.

[7] Gulyás, P. (1995b): Zooplankton Investigation in the Hungarian Upper Section of the Danube, in the Mosoni-Danube and in the Szigetköz water-bodies. - Hungarian Hydrological Society XIII National Conference, Baja 2: 543-551.

[8] Gulyás, P., Bancsi, I., Zsuga, K. (1995): Rotatoria and Crustacea fauna of the Hungarian watercourses. - Miscellanea Zoologica Hungarica 10: 21-47.

[9] Gulyás, P., Forró, L. (1999): A guide for the identification of Cladocera. - VTKV-9. KGI, Budapest, 2nd edition. pp. 24-26. (In Hungarian with English summary).

[10] Gulyás, P., Forró, L. (2001): A guide for the identification of Calanoida and Cyclopoida VTKV-14. KGI, Budapest, 2nd edition. pp. 41-42. (In Hungarian with English summary).

[11] Hammer, O., Harper, D.A.T., Ryan, P.D. (2001): PAST: Paleontological Statistics software package for education and data analysis. - Paleontologia Electronica, 4(1), 9pp.

[12] Kim, H.W., Joo, G.J. (2000): The longitudinal distribution and community dynamics of zooplankton in a regulated large river: a case study of the Nakdong River (Korea). Hydrobiologia 438: 171-184.

[13] Kobayashi, T., Shiel, R.J., Gibbs, P., Dixon, P.I. (1998): Freshwater zooplankton in the Hawkesbury-Nepean River: comparison of community structure with other rivers. Hydrobiologia 377: 133-145.

[14] Lair, N. (2006): A review of regulation mechanisms of metazoan plankton in riverine ecosystems: aquatic habitat versus biota. - River Research and Application 22: 567-593.

[15] Maria-Heleni, Z., Michaloudi, E., Bobori, D.C., Mourelatos, S. (2000): Zooplankton abundance in the Aliakmon River, Greece. - Belgian Journal of Zoology 130: 29-33. 
[16] Megyeri, J. (1955): Plankton studies in the Szeged section of the Tisza River. Hidrológiai Közlöny 35: 280-292.

[17] Megyeri, J. (1971): Zooplankton investigations in the tributaries of the River Tisza. Acta Academiae Paedagogicae Szegediensis 2: 63-73. (In Hungarian)

[18] Pourriot, R., Rougier, C., Miquelis, A. (1997): Origin and development of river zooplankton: example of the Marne. - Hydrobiologia 345: 143-148.

[19] Reckendorfer, W., Keckeis, H., Winkler, G., Schiemer, F. (1999): Zooplankton abundance in the River Danube, Austria: the significance of inshore retention. Freshwater Biology 41: 583-591.

[20] Saunders, J.F., Lewis, W.M. (1989): Zooplankton abundance in the lower Orinoco River, Venezuela. - Limnology and Oceanography 34: 397-409.

[21] Thorp, J.H., Mantovani, S. (2005): Zooplankton of turbid and hydrologically dynamic prairie rivers. - Freshwater Biology 50: 1474-1491.

[22] Zimmermann-Timm, H., Holst, H., Kausch, H. (2007): Spatial dynamics of rotifers in a large lowland river, the Elbe, Germany: How important are retentive shoreline habitats for the plankton community? - Hydrobiologia 593: 49-58. 